\section{O marketing de cidades pode ser uma boa prática, mas sua implementação é mais complexa do que se imagina}

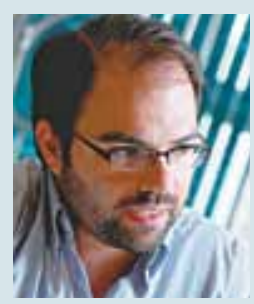

VLADIMIR

FERNANDES MACIEL

Universidade

Presbiteriana

Mackenzie

vladimir.maciel@

mackenzie.br

\title{
MARKETING DE CIDADES
}

Desde os anos 1990, em diversas partes do mundo, vem tomando corpo um debate sobre novas práticas de gestão pública inspiradas na ideia de Reforma do Estado. No seu bojo está a crescente aceitação da ideia de que os processos do Estado devem ser regidos por critérios de eficiência e eficácia, transpostos do setor privado ou nele inspirados. A tese é que se deve buscar um Estado mais enxuto, focado apenas no seu core business, e com políticas públicas pautadas por uma lógica de planejamento estratégico, voltadas à melhoria contínua.

Nesse contexto, surgiu o marketing de cidades, um conceito segundo o qual a gestão pública deve buscar uma "identidade" para a cidade e, a partir dela, buscar um "nicho de atuação". Trata-se da transposição, para o setor público local, da lógica por trás da definição de objetivos, missão e valores, uma prática originalmente surgida para uso por organizações privadas.

A cidade deve, nesse caso, buscar uma identidade que seja comercializável e rentável, de forma a atrair investimentos produtivos privados e/ou a realização de congressos, festivais ou determinados eventos esportivos, por exemplo. Isso significa pensar qual "produto" deve ser a cidade (dadas suas aptidões e características), em qual "praça" ela deve ser anunciada, e sob qual "promoção". Feiras mundiais, como a realizada em 2010 em Xangai, na China, são instrumentos para pôr em prática essa estratégia. Vender "vantagens" é objetivo de suma importância nas ações de marketing de cidades.

Cabe à cidade, portanto, encontrar seu nicho de atuação por meio da identificação dos atributos - tais como determinadas atrações naturais, ou disponibilidade de serviços e comércio diferenciados, entre muitos outros possíveis - que determinarão qual a sua vocação e qual o "produto" a ser vendido. A contrapartida desse esforço é o aumento de receitas municipais e do produto interno, como decorrência dos capitais, eventos e pessoas atraídos.

Subjacentes ao marketing de cidades estão, porém, o federalismo e sua contrapartida financeira: o federalismo fiscal. Isso porque a introdução do marketing implica competição entre as municipalidades. No Brasil, em particular, a estrutura institucional de atribuições e responsabilidades entre União, estados e municípios não dá suporte a uma competição saudável.

A competição entre municipalidades pode ser boa, mas as regras do jogo impõem incentivos nem sempre adequados. Por exemplo, municípios de uma mesma região, competindo, podem canibalizar investimentos privados e resultar em equilíbrios não cooperativos inferiores. Muitas atrações oferecidas pelas cidades demandam infraestrutura, cuja provisão é, na maioria dos casos, eficiente somente em grande escala (terminais e vias de transporte, saneamento), o que envolve altos custos para o município. A razão benefício-custo poderia ser melhorada com compartilhamento de despesas e ganhos entre um pool de municipalidades. Em suma, resultados cooperativos têm possibilidade de ser superiores aos não cooperativos, no que se refere à promoção da economia local e ao bem-estar.

Além disso, o investimento a ser atraído tem de ser passível de incorporação no uso cotidiano da cidade, integrando-se a ela e induzindo melhorias na infraestrutura, no emprego, na renda, enfim, no desenvolvimento da cidade. Esse é, por sinal, um receio que devemos ter com relação aos investimentos a serem feitos para a Copa do Mundo de 2014 e para as Olimpíadas de 2016: se mal geridos, podem resultar em projetos desvinculados da provisão de infraestrutura para o pós-evento, e desarticulados das reais necessidades das cidades-sede desses eventos. Em outras palavras, resultarão em estádios grandes e bonitos, mas que não servirão para muita coisa. 